\title{
レゾルシノールとの縮合反応を利用するアルデヒド類の蛍光光度定量
}

中原良介, ${ }^{*}$ 原 小百合, 村上沙織, 大木正伸, 松村有里子，藤本 剛，山口敬子，藤田芳一

\section{Fluorophothometric Determination of Aldehyde by Utilizing Condensation Reaction with Resorcinol}

\author{
Ryosuke NaKahara, ${ }^{*}$ Sayuri Hara, Saori MuraKami, Masanobu OKI, \\ Yuriko MATSumura, Tsuyoshi FujImoto, Takako YAMAguchi, and Yoshikazu FujITA \\ Osaka University of Pharmaceutical Sciences, 4-20-1 Nasahara, Takatsuki Osaka 569-1094, Japan
}

(Received October 29, 2008; Accepted December 22, 2008; Published online January 16, 2009)

\begin{abstract}
A simple and sensitive fluorophotometric method for the determination of aldehyde was established by utilizing condensation reaction with resorcinol. In the determination of vanillin that is one of aldehydes, the calibration curve exhibited linearity over the vanillin concentration range of $3.0-7600 \mathrm{ng} \mathrm{ml}^{-1}$ at an emission wavelength of $507 \mathrm{~nm}$ with an excitation of $410 \mathrm{~nm}$ and with the relative standard deviations $(n=5)$ of $2.5 \%, 2.0 \%$ for $7.6 \mathrm{ng} \mathrm{ml}^{-1}, 760 \mathrm{ng} \mathrm{ml}^{-1}$ of vanillin, respectively. This method was successfully applied in the assay of vanillin in cold medicine.
\end{abstract}

Key words_— fluorophothometry; aldehyde; condensation reaction; resorcinol; vanillin

\section{緒言}

アルデヒド類は, 食品添加物や芳香剂, 香料など として汎用されているほか，抗菌作用，抗炎症作 用, 鎮静作用, 免疫刺激作用など, 種々の生理活性 作用を持つ. ${ }^{1)}$ しかしその反面，食品用容器包装に 用いられるポリエチレンテレフタレート（PET） の重合工程や成形工程の熱分解物や，リグニンやセ ルロースなどの天然成分の分解物, 水中のアミンな どの有機物質と塩素処理，オゾン処理に用いる消毒 剂との反応生成物などにより生じるアルデヒド類は 大気中や土壌中, 水中に拡散し, ${ }^{2}$ 細胞原形質の夕 ンパク質を不可逆的に凝固させ，すべての細胞機能 を停止，死滅させる作用や発がん作用のほか，吸入 により呼吸器などの粘膜を刺激し, 咽頭充血, 呼吸 困難, タンパク尿などの化学物質過敏症などの元凶 になるとされており，生体において興味ある化合物 である．従来，アルデヒド類の分析法としては，公 定法3-5)で規定されている DNPH 法，フクシン亜硫 酸や，アセチルアセトン，テトラゾリウム塩等を用

大阪薬科大学臨床化学研究室

*e-mail: d06001@gly.oups.ac.jp
いた比色法, ${ }^{6-8)} \mathrm{GC}-\mathrm{MS}$ 法, ${ }^{9,10)}$ 脂肪族アルデヒド 類では, MBTH (3-methyl-2-benzothiazolinonehydrazone）を用いた比色法, ${ }^{11)}$ 芳香族アルデヒド類 では，2-アミノチオフェノールや1,2-ジアミノナ フタレン等の芳香族 1,2-ジアミンを用いた蛍光 法 ${ }^{12,13)}$ メンブラン法, ${ }^{14,15)}$ キャピラリー電気泳動 法, 16) 化学発光法 ${ }^{17)}$ など, 種々の定量法が開発され 利用されている.

一方，フルオレセインは蛍光試薬あるいは吸着指 示薬として分析化学の分野で汎用されている重要な 化合物であるが，一般的には，塩化亜鉛，硫酸，ポ リリン酸（PPA）などの縮合剂共存下，レゾルシ ノールと無水フタル酸との縮合反応によって合成さ れる. ${ }^{18)}$ また，酒石酸のような 1,2-ジカルボン酸や サッカリンなどの定性試験を行う際, レゾルシノー ルとの反応で生成するフルオレセイン様蛍光物質に

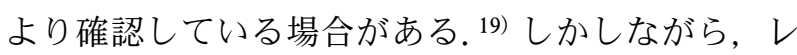
ゾルシノールと縮合反応する被分析物質を検討し, それらの定量法を開発した報告はいまだみられない.

今回, 生体関連化合物のうち, レゾルシノール類 との反応が容易に進行すると予想されるアルデヒド 類を取り上げ，これら化合物の簡便，高感度な蛍光 
2

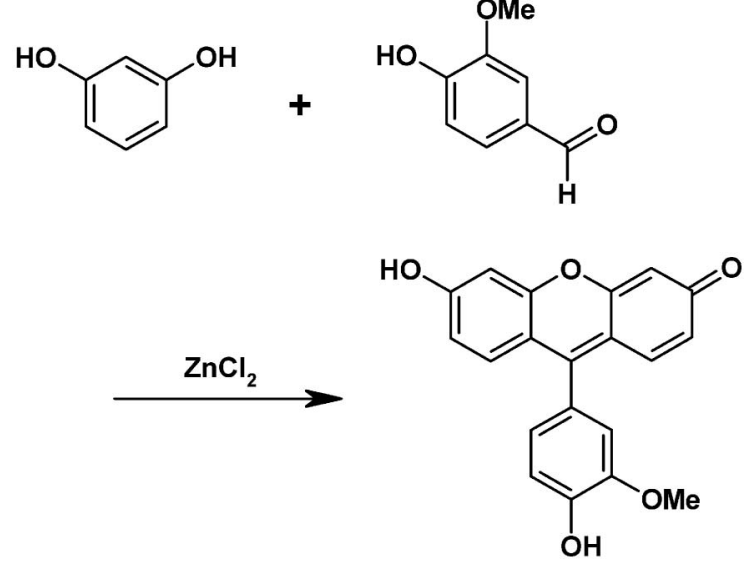

Scheme 1. Detection mechanism of Vanillin

分析法の開発を目的として系統的に検討した。その 結果, Scheme 1 に示すように, レゾルシノールと バニリンのようなアルデヒド類との縮合反応におい て，塩化亜鉛あるいは硫酸を共存させるとき，縮合 反応が加速され，効率的に発蛍光性物質が生成する ことを見い出し，本反応を用いるバニリンをはじめ とするアルデヒド類の蛍光光度定量法を確立したの で報告する.

\section{実験}

1. 試薬及び装置バニリン溶液：バニリン （和光純薬製）をメタノール溶液に溶解 $\left(1 \times 10^{-1}\right.$ $\left.\mathrm{mol}^{-1}\right)$ 乙, 用時希釈して用いた。 その他のアル デヒド類も同様に調製して用いた。

レゾルシノール溶液：レゾルシノール（和光純薬 製）をメ夕ノールに溶解 $\left(1 \times 10^{-1} \mathrm{~mol} \mathrm{l}^{-1}\right)$ し，用 時希釈して用いた。

塩化亜鉛溶液：塩化亜鉛（キシダ化学製）をメ夕 ノール溶液に溶解し， $1.0 \%$ 溶液として用いた。

その他の試薬は市販の試薬を精製せず，そのまま 用いた。また，溶液の調製にはいずれも特級メ夕 ノール（ナカライテスク製）を用いた.

蛍光スペクトル及び蛍光強度の測定には, 日立製 F-4500 型分光蛍光光度計で, 層長 $10 \mathrm{~mm}$ の石英製 セルを用いた。旭テクノグラス社製 ALB-121 型 ア ルミブロック恒温槽を用いて加熱反応を行った.

\section{2. 定量操作 共栓試験管に $1.0 \times 10^{-2} \mathrm{~mol} \mathrm{l}^{-1}$} レゾルシノールメタノール溶液 $1.0 \mathrm{ml}, 1.0 \% \mathrm{ZnCl}_{2}$ メタノール溶液 $0.5 \mathrm{ml}$ を加え, ついで 3.0-7600 $\mathrm{ng}$ $\mathrm{ml}^{-1}$ のバニリンメタノール溶液を $0.5 \mathrm{ml}$ 加え, メ

タノールで全量 $2.5 \mathrm{ml}$ とし，よくかく汼する. 次 に，共栓試験管にセミミクロ蒸留管を付し，アルミ ブロック恒温槽中で, $120^{\circ} \mathrm{C} 60$ 分加熱反応させた のち，一定量のメタノールで蒸留管をよく洗浄し， 洗液とともに全量 $10 \mathrm{ml}$ の試料溶液とする. 次に, 同様に処理して得た空試験溶液（Blank）と試料溶 液（Sample）の蛍光強度をそれぞれ励起波長 410 $\mathrm{nm}$ ，蛍光波長 $507 \mathrm{~nm}$ で測定した值を $\mathrm{S}$ 及び $\mathrm{B}$ と し, 蛍光強度差 $[\mathrm{RFI}=(\mathrm{S}-\mathrm{B}) / \mathrm{B}]$ の值を求めた 検量線よりバニリン濃度を求める.

\section{実 験 結 果}

\section{1. アルデヒドの選定及び反応化学種の検討}

予備的検討として，レゾルシノールと縮合反応す るアルデヒド類を選定する目的で，バニリン，エチ ルバニリン，アニスアルデヒド，シンナムアルデヒ ド，アミルシンナムアルデヒド，ペリルアルデヒ ド，シトロネラール，フルフラール，ベンズアルデ ヒド，プロピオンアルデヒド，ピリドキサールなど 種々のアルデヒド類を比較検討した。その結果，芳 香族アルデヒド類，特にバニリンにおいて高い蛍光 強度を示す蛍光物質が生成することを認めた。した がって，本実験においては，アルデヒド類として， 化学的に安定で用途が広いバニリンを選定した。次 に，アルデヒドのバニリンと縮合反応をする反応化 学種であるレゾルシノール誘導体について，種々検 討した。レゾルシノール誘導体としては，レゾルシ ノール，2-メチルレゾルシノール，4-ブロモレゾル シノール，フロログルシノールについて検討した. その結果，本反応においては，レゾルシノールを反 応させたとき Sample の縮合生成物が高い蛍光強度 を示し， RFIが最大值を示したので，レゾルシノー ルを用いた。

2. 反応時の縮合剂の検討 レゾルシノールと アルデヒド類の縮合反応は，縮合剂共存下ではその 反応が加速される，また，縮合剤の種類によっては 生成する蛍光物質の化学種が相違し, 生成率も変化 すると考えられるので，レゾルシノールとバニリン との縮合反応時における縮合剂について検討した。 その結果, Table 1 に示すように, メタンスルホン 酸，リン酸，ポリリン酸（PPA），硫酸，塩化亜 鉛，塩化アルミニウム，酸化亜鉛などのうち塩化亜 鉛，塩化アルミニウムのような金属塩を用いると 
Table 1. Effect of Condensation Agents

\begin{tabular}{ll}
\hline \hline Condensation agents & RFI \\
\hline $\mathrm{ZnCl}_{2}$ & 6.11 \\
$\mathrm{AlCl}_{3}$ & 5.98 \\
$\mathrm{PPA}$ & 0.12 \\
$\mathrm{CH}_{3} \mathrm{SO}_{3} \mathrm{H}$ & 1.87 \\
$\mathrm{H}_{2} \mathrm{SO}_{4}$ & 0.01 \\
$\mathrm{ZnO}$ & 0.85
\end{tabular}

Vanillin: $76 \mathrm{ng} \mathrm{ml}^{-1}$, resorcinol: $1.0 \times 10^{-3} \mathrm{~mol} \mathrm{l}^{-1}$, condensing agents: $0.05 \%$ solution, EX: $410 \mathrm{~nm}$, EM: $507 \mathrm{~nm}$.

き，高い蛍光強度を示した．今回は，メタノールへ の溶解性及び低濃度バニリンの定量性の面で優れて いる塩化亜鉛を用いることにした。

\section{3. 塩化亜鉛濃度の検討 塩化亜鉛 $\left(\mathrm{ZnCl}_{2}\right)$} 濃度としては, $1.0 \% \mathrm{ZnCl}_{2}$ メ夕ノール溶液を $0.25-$ $2.0 \mathrm{ml}$ 添加した結果, $0.5 \mathrm{ml}$ 付近で最も高い蛍光強 度を得た。したがって, 以下の操作は， $1.0 \% の$ $\mathrm{ZnCl}_{2}$ メタノール液を $0.5 \mathrm{ml}$ 添加することにした。

4. レゾルシノール濃度の検討 用いるレゾル シノール濃度を検討したところ， $1.0 \times 10^{-3}-1.0 \times$ $10^{-1} \mathrm{~mol} \mathrm{l}^{-1}$ のそれぞれを $1.0 \mathrm{ml}$ 添加した結果, $1.0 \times 10^{-2} \mathrm{~mol} \mathrm{l}^{-1}$ レゾルシノール $1.0 \mathrm{ml}$ 付近で最 も高い蛍光強度を得ることができた．したがって， 以下の操作には, $1.0 \times 10^{-2} \mathrm{~mol}^{-1}$ のレゾルシノー ルメタノール溶液を $1.0 \mathrm{ml}$ 加えることにした。

\section{5. 反応温度と反応時間の検討 本縮合反応に} おける反応温度として $110-170^{\circ} \mathrm{C}$ の範囲を, 反応時 間としては，分析操作の迅速性，簡便性を考慮し， 60 分以内の加熱時間を選び検討した結果，加熱温 度が $120^{\circ} \mathrm{C}$ において縮合生成物の蛍光強度が最大で あり，室温放置後の溶媒への溶解性にも優れてい た。さらに，反応時間として 30-120 分を選定し， 反応温度 $120^{\circ} \mathrm{C}$ において再度加熱時間を検討した結 果，60 分間加熱反応させるとき，縮合生成物の RFI が最大になった。したがって，以下の操作は， 加熱温度 $120^{\circ} \mathrm{C}$, 加熱反応時間 60 分を用いること にした.

6. 蛍光スペクトルの測定 定量操作にしたが って，Blank 及び Sample の蛍光スペクトルを測定 した. その結果，Fig. 1 に示すように，バニリン濃 度の増加に従い，蛍光波長 $507 \mathrm{~nm}$ 付近に蛍光極大 スペクトルの出現が認められた。本反応は, Scheme 1 に示す反応機構を経ると推察され，本蛍

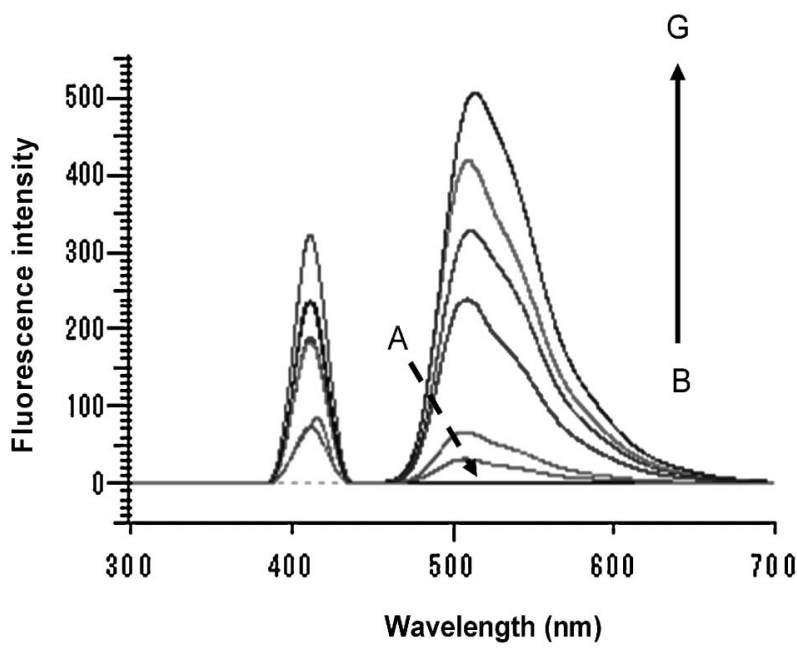

Fig. 1. Fluorescence Emission Spectra of Sample and Blank Solution

A: blank solution, B-G: reaction solution of resorcinol with vanillin (38, 76, 190, 380, 570, $760 \mathrm{ng} \mathrm{ml}^{-1}$, respectively). Resorcinol: $1.0 \times 10^{-3}$ moll $1^{-1}, \mathrm{ZnCl}_{2} 0.05 \%$ solution, EX: $410 \mathrm{~nm}$, EM: $507 \mathrm{~nm}$.

光スペクトルから発蛍光物質がフルオレセイン様物 質であることを認めた。

7. 検量線の作成 定量操作に従ってバニリン の検量線を作成したところ，バニリン 3.0-7600 ng $\mathrm{ml}^{-1}$ と非常に広い濃度範囲で, 相関係数が $\mathrm{r}=$ 0.999 と高い相関を示す良好な直線を得ることがで きた. また，バニリン濃度 $7.6 \mathrm{ng} \mathrm{ml}^{-1}, 760 \mathrm{ng} \mathrm{ml}^{-1}$ での相対標準偏差（RSD）は， $\mathrm{RSD}=2.5 \%(n=5)$, $\mathrm{RSD}=2.0 \%(n=5)$ と再現性にも優れていた。本法 は，報告されている比色法，メンブラン法10,11)の 1000 倍, キャピラリー電気泳動法 ${ }^{12)}$ の約 600 倍, 化学発光法 ${ }^{13)}$ の約 20 倍を示し，また芳香族 1,2-ジ アミン等を用いた蛍光分析法, GC-MS 法と比べほ ぼ同等の定量感度を示すとともに，操作法が簡便で あり，定量範囲は極めて広く，再現性にも優れてい る.

8. 共存物質の影響本法を実試料への適用を 目的として，それに伴う影響が予想される共存物質 について，バニリン $7.6 \mathrm{ng} \mathrm{m}^{-1}$ において検索し た。その結果，Table 2 に示すように，陽イオン， 陰イオンの共存物質について検討を行つた結果，多 量共存下においても比較的妨害が少ないことを認め た.さらにビタミン類, クエン酸, シュウ酸, カフ エイン，グルコース，アミン類などの有機化合物の 共存についても検討したが，いずれも妨害が小さい ことを認めた，さらに，尿素，メチルセルロース， 
Table 2. Effect of Foreign Substances on Determination of Vanillin

\begin{tabular}{|c|c|c|c|}
\hline Substance & $\mathrm{ng} \mathrm{ml} \mathrm{l}^{-1}$ & $\begin{array}{l}\text { Mole } \\
\text { ratio }\end{array}$ & $\begin{array}{c}\text { Recovery } \\
(\%)\end{array}$ \\
\hline None & - & - & 100.0 \\
\hline $\mathrm{Cu}(\mathrm{II})$ & $6.4 \times 10^{2}$ & 20 & 150.0 \\
\hline $\mathrm{Fe}(\mathrm{II})$ & $2.8 \times 10^{3}$ & 100 & 95.0 \\
\hline $\mathrm{Ca}(\mathrm{II})$ & $1.0 \times 10^{3}$ & 50 & 99.6 \\
\hline $\mathrm{Al}(\mathrm{III})$ & $1.4 \times 10^{3}$ & 100 & 103.8 \\
\hline $\mathrm{NaCl}$ & $2.9 \times 10^{3}$ & 100 & 106.7 \\
\hline $\mathrm{NH}_{4} \mathrm{Cl}$ & $2.7 \times 10^{3}$ & 100 & 96.7 \\
\hline $\mathrm{NaF}$ & $2.1 \times 10^{3}$ & 100 & 92.6 \\
\hline $\mathrm{KI}$ & $8.3 \times 10^{3}$ & 100 & 105.6 \\
\hline $\mathrm{KNO}_{3}$ & $5.1 \times 10^{3}$ & 100 & 84.1 \\
\hline $\mathrm{Na}_{2} \mathrm{CO}_{3}$ & $5.3 \times 10^{3}$ & 100 & 107.4 \\
\hline $\mathrm{K}_{3} \mathrm{PO}_{4}$ & $1.1 \times 10^{4}$ & 100 & 97.0 \\
\hline Thiamine & $1.5 \times 10^{4}$ & 100 & 111.6 \\
\hline Rivoflavin & $1.9 \times 10^{3}$ & 10 & 107.9 \\
\hline Ascorbic acid & $8.8 \times 10^{2}$ & 10 & 100.1 \\
\hline Citric acid & $9.6 \times 10^{3}$ & 100 & 94.1 \\
\hline Oxalic acid & $6.6 \times 10^{3}$ & 100 & 103.0 \\
\hline Caffeine & $1.1 \times 10^{4}$ & 100 & 100.0 \\
\hline Glucose & $9.0 \times 10^{3}$ & 100 & 100.7 \\
\hline Glycine & $3.8 \times 10^{3}$ & 100 & 104.7 \\
\hline Cystein & $6.1 \times 10^{2}$ & 10 & 95.5 \\
\hline Urea & $3.5 \times 10^{5}$ & 250 & 112.6 \\
\hline Methyl cellose & $1.2 \times 10^{8}$ & - & 117.8 \\
\hline Starch & $1.1 \times 10^{8}$ & - & 100.0 \\
\hline HSA & $1.3 \times 10^{8}$ & - & 112.7 \\
\hline Benzoic acid & $6.1 \times 10^{3}$ & 100 & 114.9 \\
\hline 2,4-ihydroxybenzoic acid & $5.8 \times 10^{3}$ & 75 & 96.7 \\
\hline$m$-Formylbenzoic acid & $7.5 \times 10^{2}$ & 10 & 99.3 \\
\hline Methylbenzoic acid & $6.8 \times 10^{3}$ & 100 & 100.0 \\
\hline Benzyl alcohol & $1.1 \times 10^{4}$ & 125 & 101.0 \\
\hline Acetic acid & $2.3 \times 10^{3}$ & 75 & 99.5 \\
\hline Formaldehyde & $1.5 \times 10^{3}$ & 100 & —* \\
\hline Benzaldehyde & $5.3 \times 10^{3}$ & 100 & —* \\
\hline
\end{tabular}

Vanillin: $7.6 \mathrm{ng} \mathrm{ml}^{-1}$, resorcinol: $1.0 \times 10^{-3} \mathrm{moll}^{-1}, \mathrm{ZnCl}_{2}: 0.05 \%$ solution, EX: $410 \mathrm{~nm}$, EM: $507 \mathrm{~nm} .{ }^{*}$ undetermined.

タンパク質（ヒト血清アルブミン， HSA）などの 共存についても比較的妨害がなく，良好な結果を得 ることができた。 なお，ホルミル基を含まないバニ リン類似構造の芳香族化合物の共存もほとんど影響 がみられなかったが，アルデヒド類のホルムアルデ ヒド, ベンズアルデヒドの共存は, メタノール不溶 生成物が生成し妨害した.

9. 他のアルデヒド類の反応性バニリン以外 のアルデヒド類についてバニリンの定量操作を用い 検量線を作成した。Table 3 に示すように芳香族ア
Table 3. Determination of Aldehydes

\begin{tabular}{lrcc}
\hline \hline \multicolumn{1}{c}{ Sample } & $\begin{array}{c}\text { Concentration } \\
\text { range } \\
\left(\mathrm{ng} \mathrm{ml}^{-1}\right)\end{array}$ & $\begin{array}{c}\mathrm{DL}^{a)} \\
\left(\mathrm{ng} \mathrm{ml}^{-1}\right)\end{array}$ & $\begin{array}{c}\text { Correlation } \\
\text { coefficient }\end{array}$ \\
\hline $\begin{array}{l}\text { Vanillin } \\
\begin{array}{l}\text { z-Dimethylaminoben- } \\
\text { zaldehyde }\end{array}\end{array}$ & $3.0-7600$ & 1.63 & 0.999 \\
$\begin{array}{l}\text { Propionaldehyde } \\
\text { Ethylvanillin }\end{array}$ & $9.2-2000$ & 1.85 & 0.999 \\
\hline
\end{tabular}

Resorcinol: $1.0 \times 10^{-3} \mathrm{moll}^{-1}, \mathrm{ZnCl}_{2}: 0.05 \%$ solution, $\mathrm{EX}: 410 \mathrm{~nm}$, EM: $507 \mathrm{~nm}$. a) Detection limit $=3.3 \sigma /$ slope.

Table 4. Analytical Results of Vanillin in Cold Medicine

\begin{tabular}{|c|c|c|c|c|}
\hline \multirow[b]{2}{*}{ Sample } & \multicolumn{2}{|c|}{ Content/mg } & \multirow{2}{*}{$\begin{array}{c}\mathrm{RSD}_{(\%)}^{* 2} \\
\text { (\%) }\end{array}$} & \multirow{2}{*}{$\begin{array}{c}\text { Recovery }{ }^{* 2} \\
(\%)\end{array}$} \\
\hline & $\begin{array}{l}\text { Nominal } \\
\text { amount }\end{array}$ & $\begin{array}{l}\text { Present } \\
\text { method }\end{array}$ & & \\
\hline $\mathrm{A}^{* 1}$ & 0.52 & 0.50 & 7.4 & 109.1 \\
\hline
\end{tabular}

Sample A: Ingredients-vanillin, acetaminophen, $d l$-methyl ephedrine hydrochloride, anhydrous caffeine, glycyrrhetic acid, cinnamic acid, gingerol, phyllodulcin, $l$-menthol, $d$-borneol, eugenol, anhydrous calcium hydrogen phosphate. ${ }^{* 1}$ : An aliquot of powder exactly weighted, was dissolved in methanol by means of shaking, the solution was filtered, and then the vanillin was determined by the standard procedure, ${ }^{* 2}$ : mean of 5 determinations.

ルデヒド類のアミルシンナムアルデヒド, エチルバ

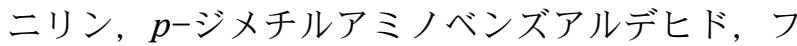
ルフラール，ペリルアルデヒド，ピリドキサール， 脂肪族アルデヒドのプロピオンアルデヒドなどを検 討した． 類似構造を示す芳香族のアルデヒド類のエ

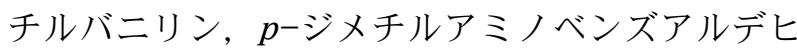
ド，脂肪族のアルデヒド類のプロピオンアルデヒド などにおいてもバニリンとほぼ同等の感度で検量線 を作成することができたが，アミルシンナムアルデ ヒド，ピリドキサールなどにおいては十分な感度が 得ることができなかった。 今後, これらについては バニリンの定量操作とは異なる分析条件の設定が必 要であると考えられる。

10. 実試料への応用 本法の実試料への応用 として, 市販のかぜ薬を用いて検討した. その結果 を Table 4 に示すが, 添加回収率 $109.1 \%(n=5), 5$ 回での相対標準偏差（RSD）は， $7.4 \%$ という結果 が得られた。本法はこのような多成分を含有する複 合製剂中においてもバニリンの定量が可能であり， バニリンをはじめ実試料中のアルデヒド類の測定に 十分適用できると考えられる. 


\section{考察}

レゾルシノールとアルデヒド類との縮合反応の 際，塩化亜鉛を触媒として共存させると，縮合反応 が加速され，効率的に発蛍光物質が生成することを 見い出した（Scheme 1)。バニリンの場合，本反応 の利用により，3.0-7600 ng ml $\mathrm{nl}^{-1}$ とダイナミックレ ンジの広い濃度範囲のバニリンを励起波長 410 $\mathrm{nm}$ ，蛍光波長 $507 \mathrm{~nm}$ で蛍光光度定量することが できた。本法は，共存物質の影響も少なく再現精度 にも優れた，簡便・高感度なバニリン測定法であ る。本法を市販複合製剤（かぜ薬）中のバニリン分 析に応用したところ，測定值，回収率とも良好な結 果が得られ，実試料中のバニリン測定法として十分 適用できることが示唆された。

\section{REFERENCES}

1) Japan Food Additives Association, JSFA-VII, D-1040 (1999).

2) Ookado Y., Kawamura Y., Tanamoto K., Syokueishi, 46, 218 (2005).

3) US Environmental Protection Agency, EPA Method, TO-11 (1988).

4) Japanese Standards Association, JIS K 0303 (2004)

5) Kankyotyoutaikihozenkyokukiseika, Yuugaitaikiosenbussitsusokuteihou Manual, (1997).
6) The Vitamin Society of Japan, Vitamin and Medicine (1998).

7) Sherif E. 1, Walash M.I.,Osman A., Anal. Lett., 30, 1881 (1997).

8) Shannnon S. K., Barany G., J. Comb. Chem., 6, 165 (2004).

9) Glaze W. H., Koga M., Cancilla D., Environ. Sci. Technol., 23, 838-847 (1989).

10) Sugaya N., Nakagawa T., Sakurai K., J. Health Sci., 47, 21-27 (2001).

11) "Bunsekikagaku Handbook," Asakura syoten, (2002) .

12) Katayama M., Mukai Y., Taniguchi H., Anal. Sci., 3, 565 (1987).

13) Hara S., Nakamura M., Yamaguchi M., Anal. Chim. Acta, 291, 189 (1994).

14) Qureshi M., Qureshi S., Singhal S.C., Anal. Chim. Acta, 53, 361 (1971).

15) Luque M., Perez E. L., Valcarcel M., Anal. Chim. Acta, 410, 127 (2000).

16) Ohashi M., Omae H., Imai S., J. Chromatogr. $A$, 1138, 262 (2007).

17) Potamia M. T., Calokerinis A., Talanta, 71, 208 (2007).

18) Nihonyakkyokuhoukaisetsusyohennsyuiin, JP 15, C, 3654-3658 (2001).

19) Japan Food Additives Association, JSFA-VII, 266 (1999). 